\title{
材料教育
}

\section{移動実験車“リカレンジャー”の 人気の背景}

松 浦 真*

\section{1. は じめに}

リカレンジャーとは図 1 に示す移動実験車につけられた愛 称である. 両ウイング式の箱型コンテナを持つ 4 トントラ ックで，荷台には出前体験教室で使用する実験道具が詰まれ ている．ウイングを持ち上げると荷台をサイエンスショーの 舞台としても利用できる、派遣要請に応えどこにでも移動 し, サイエンスショーや体験教室を実施することが可能であ る. 車体のデザインは宮城高専の学生によるものである. 現 在では移動実験車の愛称であるリカレンジャーは我々の出前 体験教室の活動そのものを表している．このリカレンジャー の活動がスタートしたのは2004年度からである．スターと したころは出動要請も全く無い状態が続いたが，実際に活動

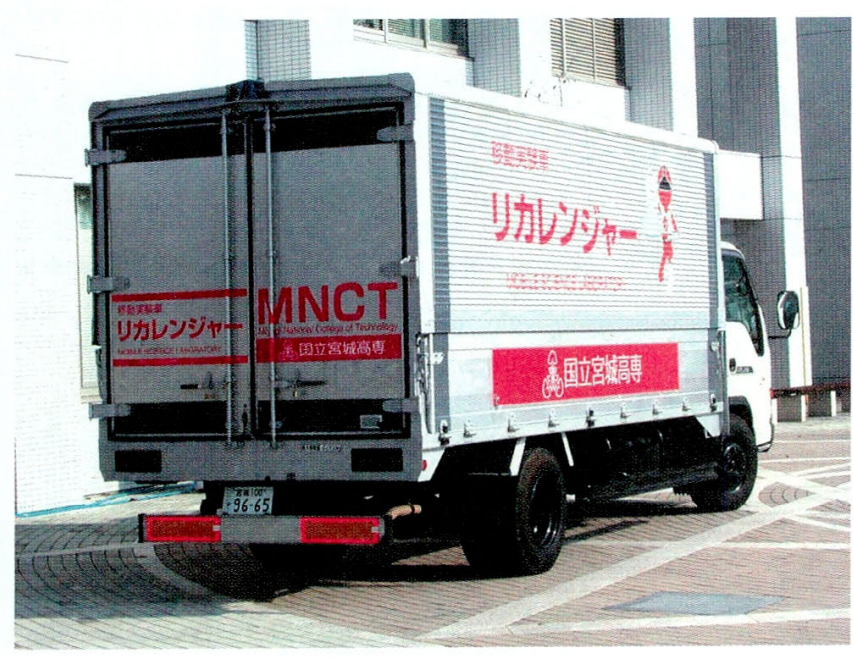

図 1 両ウイング式 4 トントラックの移動実験車「リ カレンジャー」.
をはじめたところマスコミに大きく取り上げられたこともあ り，予想を超える人気となった。ここではこのような活動が 何故これほどの人気があるのか, その理由と背景, さらに今 後こうした理科離れに対する活動を発展させるための課題に ついて述べる.

\section{2.リカレンジャーの誕生と成長の記録}

（1）中学生を対象とした「わくわく実験·科学教室」の実 践

1997年度より宮城高専では総合科学系理数科の教員を中 心に中学生を対象とした「わくわく実験・科学教室」を始め た、これは物理抢よび化学の実験とコンピュータ実習をセッ トにした体験教室で, 当時はまだこのような体験教室が少な かったこ上もあり第 1 回目は予想を超える200名近い受講者 があり, 急遽予定を 2 日間に延長して実施した。 その後こ の体験教室は 10 年間継続され今日に至っている。しかし, 同様な体験教室がいくつか開催されるようになり, 受講者も 次第に減少する傾向にあった。このことから理科体験教室は これまでのように受講者が会場に足を運ぶのではなく, こち らから現場に出向いていく出前タイプの体験教室に变わるこ とが必要と考えた。 そこで, 文部科学省の科学研究費に「移 動実験車による体験教室」をテーマとして申請した．幸い 2004年度から期間 3 ヶ年の課題として採択された（研究費 980万円).

\section{（2）文部科学省科学研究費の採択と準備活動}

採択直後の課題は移動実験車となる車の購入とその車に実 験室としての機能を持たせる等の準備活動が中心となった. 車はインターネットで中古の 4 トントラックを購入した. トラックの愛称を学内で募集し, リカレンジャーと名づけ

* 宮城工業高等専門学校特任教授(

The Reasons Why So High Reputation Can Be Obtained for the Science Activities Using Mobile Laboratory Named RIKARANGER; Makoto Matsuura (Miyagi National College of Technology, Natori)

Keywords: mobile laboratory, delivery science-seminar, science workshop, science education, engineering for production 2007 年 6 月 4 日受理 
た．また車の箱型荷台に描くデザインを学生から募集した。 そのときに生まれたのが図 2 のリカレンジャーのロゴであ る. 次に学内の教員に協力を呼びかけた結果, 10 名ほどの 教員から実験テーマとして20数テーマが集まった，活動の 目的と内容を知らせるため市内の全ての中学校に案内の手紙 とパンフレットを送ったが，反応はなかった。こうして1 年目が終わるころには出動の準備は整ったものの出動要請は 全くなかった。しかし，第 1 回目の行事として 10 月に高専 の学園祭行事としてリカレンジャーによるサイエンスショー を企画したところ(図 3)これを見た保護者の方から是非地元 に来て欲しいという声が掛かり始めた。

\section{（3）本格的活動}

その後はホームページ (http://www.miyagi-ct.ac.jp/gg/ sougou/rikaranger/rikaranger.htm) を立ち上げたことや口 コミで次第に評判が広がり出動要請が少しずつ増え始めた. 1 つの転機は 2 年目の 11 月に開かれた宮城県児童館職員の研 修会であった。そこで“科学めそび”の体験教室を担当し，

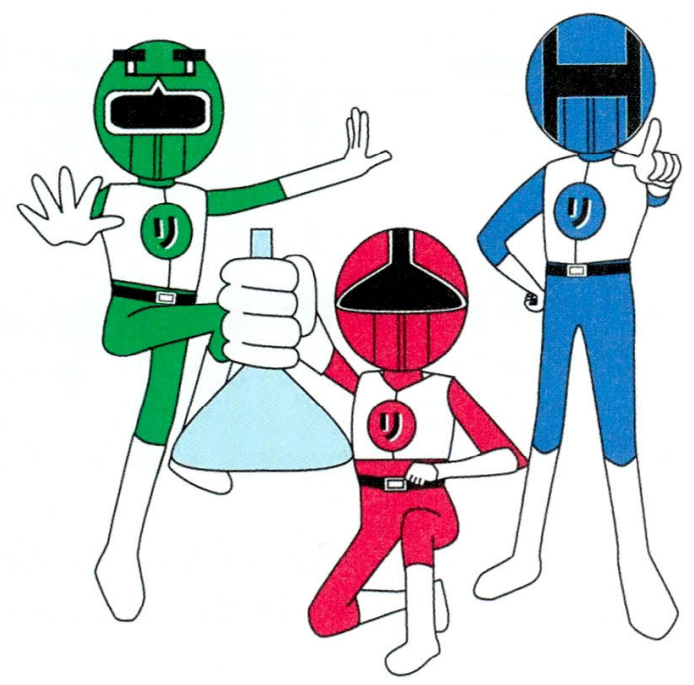

図2 リカレソジャーのキャラクターデザイン。

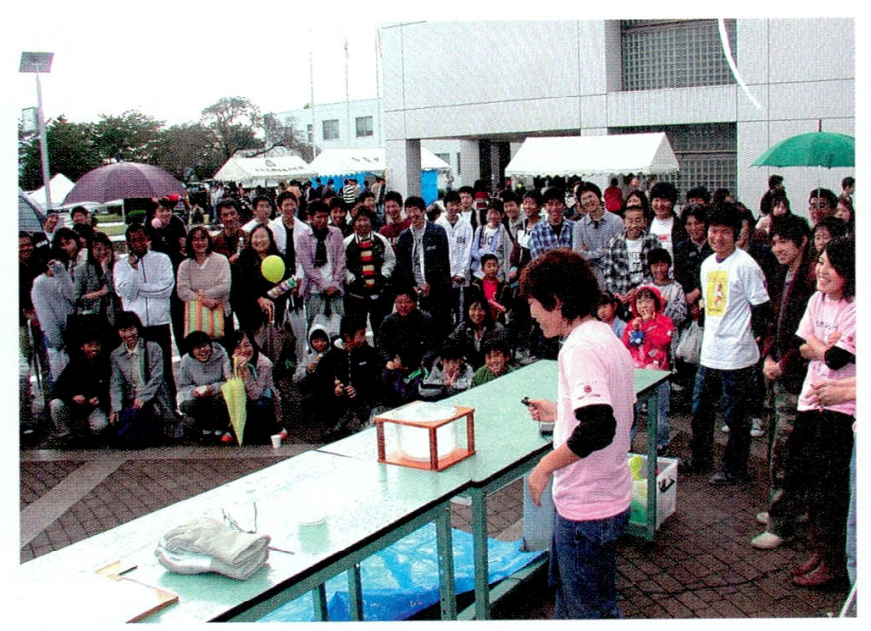

図 3 学園祭でのサイエンスショーの風景.
100名以上の児童館職員に「光」，「音」，「電気」をテーマと するいくつかの科学遊びを体験してもらった．この体験教室 が好評であったため装年から児童館より多くの出動要請が来 るようになった。 リカレンジーがさらに広く知られるよう になったのは2006年 6 月に市内の小学校で 4 学年全員 $(200$ 名)上保護者(100名)を加えた約300名を対象とする体験教室 を実施したことであった。このように多人数を対象とする体 験教室の試みは始めてであったが，単に見せるだけのショー に終わらせることなく, 全員が実験に参加できるよう内容も 工夫した (図 4). また, アシスタント学生 20 名, 教職員 7 名 の協力を得ることができ，成功裏に終えることができた。こ の模様は生中継も含め地元の 3 つのテレビ局で放映され， 新聞にも大きく取り上げられた。これをきっか性にリカレン ジャ一の名前が広がり, その後も度々テレビや新聞の取材を 受けることになった．表 1 は2006年度の出動内容を示す.

\section{3.リカレンジャ一活動が成功した理由}

本年度の 5 月の段階でリカレンジャーの派遣依頼はすで に50件を越え，今年度の申し込みを終了せざるを得なくな った.リカレンジャーがこのように引く手あまたの人気とな った理由は次のことが考えられる.

第一に子供達は科学遊びやものづくりが大好きであること.

青少年の理科離れが進んでいると言われるが，リカレンジ ャ一の活動をと扎して見る限り子供達, さらには保護者も科 学的好奇心が強く, 科学遊びやものづくりが大好きであるこ とがわかる。

第二にイメージキャラクターを作ったこと.

移動実験車にリカレンジャーという名前をつけ, そのイメ ージキャラクターをデザインしたことで，この出前体験教室 の活動が子供や一般市民に親しみを感じさせ，マスコミにも 注目されるようになった。

第三に参加者自らが体験することを重視した内容の体験教 室を実施していることである.

宮城高専に於ける10年間にわたる「わくわく実験・科学

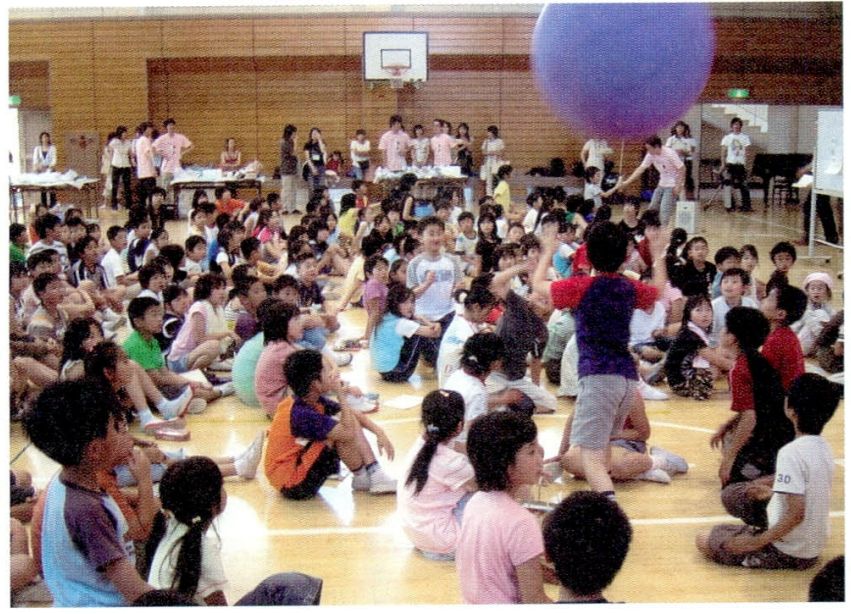

図4300名を対象とした出前体験教室の模様. 
表 1 2006年度のリカレンジャーの活動内容.

\begin{tabular}{|c|c|c|c|c|}
\hline 回 & 月/日 & 主催団体 & 参加人数 & 行事 内 \\
\hline 1 & $5 / 22$ & 南吉成東 B 地区子供会 & 55 & $\mathrm{~S}$ : 液体窒素と気体の性質, 光のマシシック $\mathrm{W}$ : 分光器と万華鏡の製作 \\
\hline 2 & $5 / 27$ & 松陵児童センター & 38 & $\mathrm{~S}$ : 強力磁石の不思議な現象 $\mathrm{W}$ : クリップモータ作り \\
\hline 3 & $6 / 29$ & 広瀬小学校 4 学年 & 297 & 液体窒素と気体の性質, ドライアイスの実験 \\
\hline 4 & $7 / 15$ & 中山市民センター & 50 & $\mathrm{~S}$ : 液体窒素と気体の性質, 光のマジック $\mathrm{W}$ : 分光器と万華鏡の製作 \\
\hline 5 & $7 / 29$ & 桜地区子供会育成会 & 30 & $\mathrm{~S}$ : 液体窒素と気体の性質 W：スピーカーとクリップモータつくり \\
\hline 6 & $8 / 17$ & 増田児童館＋公民館 & 67 & $\mathrm{~S}$ : 液体窒素と気体の性質 $\mathrm{W}$ : 分光器の製作と光の観察 \\
\hline 7 & $8 / 23$ & 角田市立桜小学校 & 30 & $\mathrm{~S}$ ：ドライアイスの実験 W：ドライアイスによるアイスクリームづくり \\
\hline 8 & $9 / 6$ & 八木山南児童館 & 50 & $\mathrm{~S}$ : 音の性質 $\mathrm{W}$ : 糸電話の製作 \\
\hline 9 & $9 / 13$ & 名取第 2 中学 2 学年 & 230 & $\mathrm{~S}$ : 光の性質 (3 原色, 回折, 偏光) $\mathrm{W}$ : 簡易分光器の製作と光の観察 \\
\hline 10 & $10 / 21$ & 宮城高専学園祭 & 200 & サイエンスショーとカの性質 \\
\hline 11 & $10 / 24$ & 㭷木小学校 2 学年 & 191 & $\mathrm{~S}$ : 不思議な風の力 $\mathrm{W}:$ プラトンボ製作 \\
\hline 12 & $10 / 28$ & 下増田小学校 & 約 100 & $\mathrm{~S}:$ 空気の力 $\mathrm{W}:$ ブーメラン作り \\
\hline 13 & $11 / 11$ & 福沢市民センター & 25 & $\mathrm{~S}$ : 強力磁石の性質 $\mathrm{W}:$ クリップモータ作り \\
\hline 14 & $11 / 15$ & 太白区中央児童館 & 30 & $\mathrm{~S}$ : 強力磁石の性質 $\mathrm{W}:$ クリップモータ作り \\
\hline 15 & $12 / 16$ & 南光台東児童センター & 30 & サイエンスショーとスライム \\
\hline 16 & $1 / 18$ & 館腰児童センター & 40 & $\mathrm{~S}$ : 静電気実験 $\mathrm{W}$ : 備長炭電池づくり \\
\hline 17 & $3 / 24$ & 東北電力プラザ & 約 1700 & $\mathrm{~S}$ : 低温実験と強力磁石 $\mathrm{W}$ ：太陽電池ヘリコプター, クリップモータ \\
\hline
\end{tabular}

（注）表中 S はサイエンスショーを W はワークショップを示す.

教室」で得られた理科実験のノウハウはこのリカレンジャー の実験に役立っている，リカレンジャーで実施する教室の企 画の多くは, サイエンスショーとワークショップからなる. サイエンスショーも見せるだけでなく出来るだけ参加者に実 際に体験してもらうよう工夫している. ワークショップでは ものづくりを体験することで製作する喜びと達成感を得るこ とを目指している．ドライアイスをテーマとした場合の企画 の例を以下に示す.

ドライアイスを用いるサイエンスショーの内容

（1）ドライアイスの気化による体積膨張を見る：細かく砕い たドライアイスをビニール袋に入れて振る。

(2) ドライアイスロケット：フィルムケースに細かく砕いた ドライアイスを入れて蓋をする. 1, 2 分で大音響と共に蓋 が飛び出す.

（3）ドライアイスの滑走体：底に穴が開いたフィルムケース に細かく砕いたドライアイスを入れ，蓋をした後，平らな 机の上に徖いて走らせる.

（以上(1)-(3)は参加者にも実際に実験をしてもらう.）

(4) 二酸化炭素の性質

(a) ローソク消し(演示実験) : ポリバケツに水を半分ほ ど入れる.これに砕いたドライアイスを入れる.ロー ソク台のローソクに火をつけて二酸化炭素のガスを上 から流し达むと，ローソクの火が上から次第に消える。

(b) 紫キャベッの色素：ドライアイスを入れたペットボト ルに水と紫キャベッの色素を加える.これにアンモニア 水を適量加えると溶液の色が藍色, 紫, 赤紫と連続的に
変化する.

（5）ドライアイスの液化実験 : 図 5 のように液化器の中にド ライアイスを入れて上からピストンを強く押し込み液化さ せる.

ワークショップ: ドライアイスを使ったアイスクリーム作 り.

大き目のビニール袋に牛乳と生クリームと卵黄を入れよく 振る. 粉砕したドライアイスを入れビニール袋をよく振れ ばアイスクリームができる.

第四に移動実験車の機動性を生かし, どこでも出かけるこ とができること.

トラックには実験に必要な機材が積まれているのでどこへ でも出かけて教室を開くことが出来る. 実験を見たり体験し たりする機会にめぐまれない地域の人にとってリカレンジャ 一の活動に期待が大きい.

第五にアシスタント学生の熱心な協力があること.

リカレンジャーが出動するに当たっての事前の準備と当日 の実施にあたっては学生の協力が必須である。幸い, 宮城高 専には実験が好きで, 子供達に教えることが好きな学生が多 い. そのため多くの学生が積極的にリカレンジャーによるボ ランティア活動に参加してくれる. 現在 43 名の学生が隊員 として登録している。

第六に教職員の積極的な協力が得られていること.

この活動がスタートする時点で, 学内の教職員の協力が得 られるかどうか不安であったが実際に活動が始まると予想以 上に多くの教職員が協力してくれた. また退職した元東北大 


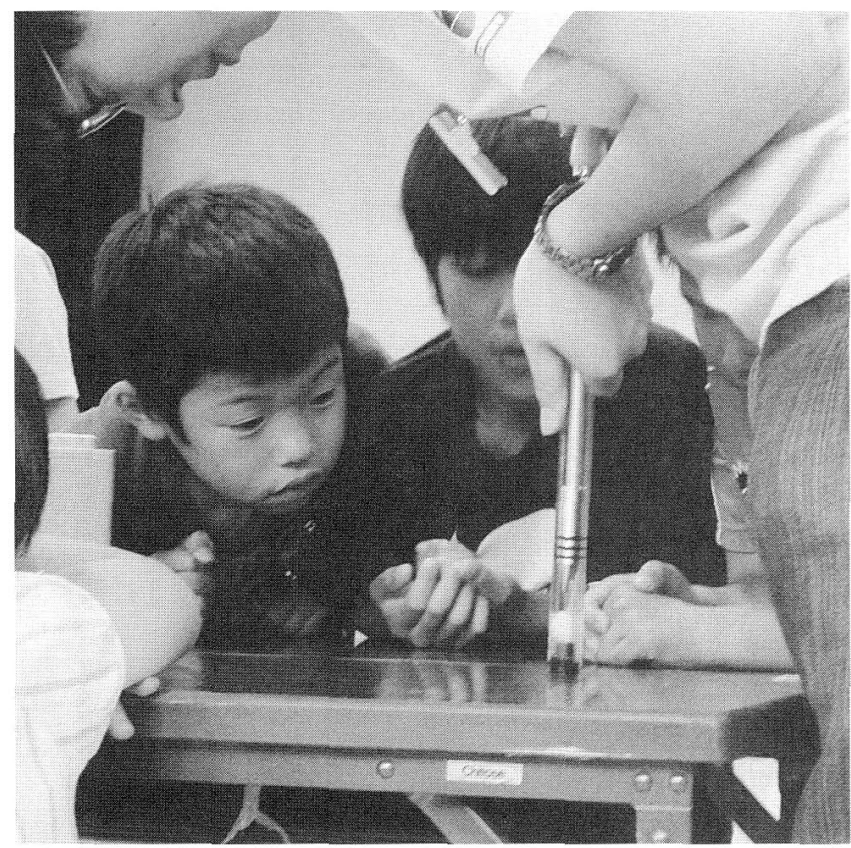

四 5 ドライアイスの液化実験の様子.

学教授の方にも協力していたたいている.

第七に無料で実施していること.

リカレンジャーの活動はボランティア活動として行なって いるため，原則無料で実施している，ただし，ワークショッ プによっては，材料費を徵収する場合もある，年間の行事経 費に制約が大きい児童館等からこの点は大いに歓迎されてい る.

\section{4.リカレンジャーの活動から得た教訓}

（1）子供達の理科に対する潜在的な興味，関心は非常に高 い.

科学の不思議さに出会って見せる驚きの表情や，ものーうく りに見せる生き生きとした表情を見ていると理科離れが杞憂 に感じられる，子供だけではなく保護者，特に母親たちも理 科実験に喜んで参加する。このような状況を見ると理科離れ は理科嫌いが原因ではなく，理科の面白さを体験する機会が 少なかったに過ぎないと思われる。

（2）「迎える」から「出掛ける」ことが，「見せる」から 「体験する」,「つくる」ことが重要である.

多くの体験教室や公開講座等老行う場合は学内で行なわれ ることが多いが，その場合，参加者は問題意識をもち，関心 が高い人を対象とすることになる。出前型の体験教室ではよ り多くの子供達を対象とすることが出来る，そのため理科へ の興味が眠っていた子供にも目を開かせる機会を与えること が可能で, 理科離れ対策としてはより効果的である. 子供達 が一番喜ぶのは自分自身で体験する時であり，体験すること

によって好奇心が目覚め，理解が深まる。

\section{5.リカレンジャ一活動の今後の課題}

\section{（1）中学校へのアプローチ}

リカレンジャーの活動は我々にとっても全く未知の活動で あり暗中模索の状態であった．3 年半の活動の結果は予想を 超える反響と人気となり大きな成果を得ることが出来た．今 後この活動を継続し，さらに発展させるためには次のような 課題がある。

リカレンジャーが最も活動したい舞台は中学校である。し かしながら現在までに出動した中学校は 1 校だけであっ た，中学校で実施した経験では中学生の反応は大変良く，な た参加したアシスタント学生もこれまでにない充実感を得て いる. 今後は中学校での出前教室を増やして行きたいが，そ のために中学校の先生上交流を深め, 中学校の理科教育の現 状を知ることも必要であろう。本た, 県や市の教育委員会と も連携を取る必要がある。

\section{（2）驚き，考えさせることが出来る実験の開発研究}

理科実験において興味ある実験，考えさせる実験の開発が 求められる.そのために体験教室で扱う実験テーマについて の研究を進めることが必要である.

\section{（3）活動の継続性とリカレンジャ一活動の全国的展開}

2006年度で 3 力年の科研費の研究期間が終了したが，継 続は認められなかった。しかし, 宮城高専の支援を受けるこ とができ，活動を継続することができた。今後は宮城高専で のリカレンジャー活動を継続させるのみならず, リカレンジ ヤーが全国に配置され, 子供達に科学の面白さとものづくり の楽しさを伝える活動が全国的に展開されることを目標に活 動してゆきたい。

最後に，このリカレンジャーの活動に協力していただいた 宮城高専の教職員, 学生さらには事務部の方々, 校長に心か ら感謝するものである。特に, ホームページの充実と活動の 立ち上げに際して協力していただん今野一弥准教授に感謝 するものである、またこの活動は文部科学省科学研究費補助 金基盤研究 B(16300257) による支援で行われたものである.

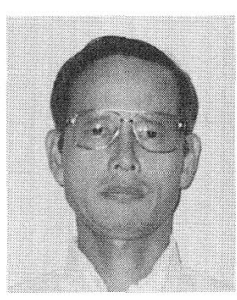

松浦 真 $\downarrow+\downarrow t+t+t+t+t \downarrow t+t+t+t+$ 1973年 東北大学大学院工学研究科博士課程修了 1973年 宮城高専 助手 1988年 宮城高専 教授 1989年-1990年 IBM ワトソン研究所客員研究員 現職

専門分野 : XAFSによる構造解析

高専での教育活動の傍ら移動契験車リカレンシャーに 上る出前体験教室を立ち上げた。研究活動として XAFSによる合金中の微量添加元素の局所構造解析 およびバルク金属ガラスの構造と安定性等，また高強 度 $\mathrm{Mg}$ 系合金の開発等の研究を行っている. 